\title{
Impact of insect-resistant GM rice on pesticide use and farmers' health in China
}

\author{
HUANG JiKun $^{1 *}$, HU RuiFa $^{2}$, QIAO FangBin ${ }^{3 *}$, YIN YanHong ${ }^{4}$, LIU HuaiJu $^{1}$ \\ \& HUANG ZhuRong ${ }^{1}$ \\ ${ }^{1}$ Center for Chinese Agricultural Policy, Institute of Geographical Sciences and Natural Resource Research, Chinese Academy of Sciences, \\ Beijing 100101, China; \\ ${ }^{2}$ School of Management and Economics, Beijing Institute of Technology, Beijing 100081, China; \\ ${ }^{3}$ China Economics and Management Academy, Central University of Finance and Economics, Beijing 100081, China; \\ ${ }^{4}$ Department of Neurology, Chinese PLA General Hospital, Beijing 100853, China
}

Received May 27, 2014; accepted September 25, 2014; published online January 8, 2015

\begin{abstract}
The economic benefits of insect-resistant genetically modified (GM) crops have been well documented, but the impact of such crops and the consequent reduction in pesticide use on farmers' health remains largely unknown. Through the analysis of the data collected from the physical examination from farmers in China, we show that GM rice significantly reduces pesticide use and the resultant not only visible but also invisible adverse effects on farmers' neurological, hematological, and electrolyte system. Hence, the commercialization of GM rice is expected to improve the health of farmers in developing countries, where pesticide application is necessary to mitigate crop loss.
\end{abstract}

pesticide use, farmers, health, genetically modified rice, insect-resistance

Citation: Huang JK, Hu RF, Qiao FB, Yin YH, Liu HJ, Huang ZR. Impact of insect-resistant GM rice on pesticide use and farmers' health in China. Sci China Life Sci, 2015, 58: 466-471, doi: 10.1007/s11427-014-4768-1

Genetically modified (GM) crops have been well documented in the literature [1,2], However, the impact of GM crops on farmers' health due to the reduction of pesticide use has not been rigorously analyzed. By 2012, GM crop areas reached 170 million hectares, benefiting dozens of millions of farmers [3]. While previous studies have indicated a reduction in acute (visible) pesticide poisoning in farmers because of GM crops [4,5], the impact of this reduction on farmers' long- or short-term invisible health has not been quantitatively analyzed.

The primary goal of the present study is to estimate the invisible health impact of pesticide reduction through the adoption of GM rice on farmers. Rice is the world's most important crop and feeds half the planet, but it recorded the

*Corresponding author (email: jkhuang.ccap@igsnrr.ac.cn; fangbin.qiao@gmail.com) highest pesticide use among cereal crops [6]. We focused on invisible health effects because they are more common and may ultimately lead to fatal disease $[7,8]$.

\section{Methods}

Two datasets were used in this study. The first dataset was based on GM and non-GM rice trials and was used to compare pesticide use between GM rice plots and non-GM rice plots. The second dataset was based on farmers' physical examinations, and used to estimate the impact of pesticide exposure on farmers' health.

\subsection{GM rice field trials}

While GM rice has not yet been commercialized, a number 
of varieties have entered pre-production trials and some have received production biosafety certificates [9]. The GM rice variety used in this study was Kefeng- 8 , which is one of the major GM rice varieties and has the potential to be commercialized in the future. Kefeng- 8 was developed to be resistant to rice stem borers through the insertion of two insect-resistant genes (Bt gene crylAc and a modified cowpea trypsin inhibitor ( $C p T I)$ gene) into the II-Youming 86 rice variety [9]. The variety was developed by the Chinese Academy of Sciences and Fujian Academy of Agricultural Sciences, and has been in pre-production trials, which is the stage just prior to the issuance of a production biosafety certificate, since 2007.

Trials for both GM and non-GM rice were conducted in three villages in Fujian province in 2010. In each village, one paddy field with $5-6 \mathrm{hm}^{2}$ and about 40 separated plots (each plot belonged to one household) was selected. Plots in each paddy field were randomly selected for the planting of either GM rice or non-GM rice varieties. Farmers who were assigned to plant GM rice received the Kefeng- 8 variety from the village leaders who helped distribute the GM rice seed. For farmers who were not assigned to plant GM rice, half of them planted II-Youming 86, and the other half planted the usual local varieties. Unfortunately, in one of the three villages, the village leader did not randomly distribute the GM rice seed to the farmers who were assigned to plant the GM rice. Therefore, we ended up with two villages that implemented both GM rice and non-GM rice trails, and one village that implemented only non-GM rice trails.

For all trials, we collected household's basic information and plot level production input and output data. Specifically, we requested that the participating households record details of (i) pesticide use and all other farm-management practices of rice production in the plots during the trials; and (ii) pesticide use in crop production in other plots not located in trial fields.

\subsection{Physical examinations and pesticide use}

The second dataset contains results from farmers' physical examinations in August 2010. We conducted the examinations in August, as this is the time when pesticides were intensively used in sampled areas. Two rounds of examinations were conducted to control for the impact of time-invariant factors; thus, analysis of the difference between these two rounds would be unaffected by the initial health situation of each individual.

The time interval between the two rounds of examinations ranged from 1 to $3 \mathrm{~d}$ in this study. Originally, we de- signed to have the second round of examination in the second day of farmers' pesticide applications because the half-lives of many pesticides are within $24 \mathrm{~h}$ though some could be longer, such as between 24 and 48 h [10]. However, during the second round of health examination in the village, some farmers were not at home, their health examinations were conducted in the second and third day after their pesticide applications. Indeed, the time interval ranged from 1 to $3 \mathrm{~d}$ can provide us additional information on the health impacts of pesticide application over different time periods (e.g., within 24, 24-48 and 48-72 h).

Prior to conducting the examinations, the study was carefully explained to farmers and each farmer included in the final sample signed an examination agreement. First, the project team met all 76 farmers who participated in the GM rice and non-GM rice field trials in the two villages, and the 60 farmers in the third village. All farmers were clearly informed that the physical examinations were merely to be used as data for academic research, and that the results would be provided to them following the examinations. In the end, we had obtained physical examination agreements from 65 farmers from the two GM rice trial villages, and 53 farmers from the third village. However, nine of these examinations were not conducted due to farmers either being away from home or failing to remember the appointment. Thus, 109 farmers received health examinations.

Health examinations included general and blood examinations. In the general examination, height, weight, and blood pressure were measured, and urinalysis, electrocardiogram, and ultrasound were performed. In addition, a historical record of the visible effects of pesticide applications was obtained from each farmer. Farmers were asked several specific questions regarding the visible effects of pesticide use such as the following: "who applied pesticides most frequently in your family?"; "during or immediately after pesticide application, did you suffer from any of the following symptoms: headache, nausea, skin irritation, digestive discomfort, or others?". If a respondent answered in the affirmative to the last question about the symptoms, the following questions were asked: "how many times did you suffer?"; "which symptom did you suffer from?"; "when did it happen?".

Dataset from blood examinations and individual interviews on pesticide application were used to assess the invisible effects of pesticide use. The following indicators were used to measure invisible effects: (i) cholinesterase $(C H E)$ and neuron-specific enolase (NSE) to assess the nervous system ${ }^{1)}$; (ii) neutrophil granulocyte percentage $(N)$ and red blood cell count $(R B C)$ to assess the hematological

1) CHE is an enzyme that measures the function of human nerve function. When pesticides enter the human body, they mix with CHE. As a result, the activity of CHE in human blood decreases [11]. On the other hand, clinical studies showed that pesticide use led to increase of NSE, another indicator of the nervous system [12]. 
system ${ }^{2)}$; (iii) chloride $\left(\mathrm{Cl}^{-}\right)$and sodium $\left(\mathrm{Na}^{+}\right)$levels to assess electrolyte balance ${ }^{3)}$. Following the collection of blood samples, farmers were asked to provide detailed information about pesticide application prior to the blood test.

\subsection{Models}

Since a number of factors may affect the magnitude of the health indicators measured in this study, the multiple regression model was applied. To determine the impact of pesticide use on these health indicators, the following model was used:

$$
\begin{gathered}
\text { Indicator }_{\mathrm{it}}=a_{0}+a_{1} * \text { Pesticide }_{\mathrm{it}}+a_{2} * \text { Characteristic }_{\mathrm{it}}+ \\
a_{3} * \text { Region }_{\mathrm{it}}+e_{\mathrm{it}} .
\end{gathered}
$$

Eq. (1) is similar to models that have been used elsewhere in the literature [11]. The dependent variable (Indicator) is a health indicator. In this study, the specific indicators are $C H E$ and NSE for the nervous system; $N$ and $R B C$ for the hematological system; and $\mathrm{Cl}^{-}$and $\mathrm{Na}^{+}$for body electrolytes.

The independent variable of interest (Pesticide) is measured by three dummy variables: $D 1$ equals 1 if the farmer applied pesticides within $24 \mathrm{~h}$ of the second blood test; $D 2$ equals 1 if the farmer applied pesticides more than $24 \mathrm{~h}$ but less than $48 \mathrm{~h}$ before the second blood test; $D 3$ equals 1 if the farmer applied pesticides more than $48 \mathrm{~h}$ but less than $72 \mathrm{~h}$ before the second blood test. The value of each of the three dummy variables was 0 , if the condition was not met. In an alternative specification, pesticide use is measured by the following: (i) the quantity of pesticide applied in the $24 \mathrm{~h}$ before the second test, (ii) the quantity of pesticide applied more than $24 \mathrm{~h}$ but less than $48 \mathrm{~h}$ before the second blood test, and (iii) the quantity of pesticide applied more than 48 $\mathrm{h}$ but less than $72 \mathrm{~h}$ before the second blood test.

Characteristic is a vector of farmer characteristics such as age, gender, and years of education. The impact of environmental conditions was assessed through the inclusion of the regional dummy variable (Region) in the equation. Finally, $i$ is the $i$ th farmer; $t$ is time; and $e$ is the error term.

It is possible that estimation using eq. (1) will yield biased results due to the endogenous problem. The unique panel data collected from the two rounds of blood tests for each farmer allowed us to estimate using the Fixed Effect (FE) model. Since the characteristic of the farmers and regional dummies are time-invariant variables during these two rounds of blood tests, the FE model can be written as follows:

$$
\Delta \text { Indicator }_{\mathrm{it}}=\beta_{0}+\beta_{1} * \Delta \text { Pesticide }_{\mathrm{it}}+\varepsilon_{\mathrm{it}},
$$

where $\Delta$ Indicator $_{\text {it }}$ is the change in each health indicator from its mean, and $\Delta$ Pesticide $_{\text {it }}$ is the change in pesticide use from its mean.

\section{Results}

Descriptive statistics illustrate that our sample of farmers was fairly typical (Table 1). Farmers cultivated an average of $0.15-0.36 \mathrm{hm}^{2}$ per household, which is lower than the average in China $\left(0.48 \mathrm{hm}^{2}\right)$, but similar to the average in Fujian province $\left(0.30 \mathrm{hm}^{2}\right)[19,20]$. Results indicate that the reduction in pesticide exposure due to the use of GM rice leads to a decrease in pesticide-associated poisoning. Our results showed that $8 \%$ of farmers who did not plant GM rice suffered from acute poisoning illnesses related to pesticide use, while none of the farmers reported any poisoning symptoms in their GM rice fields (Table 1). Statistics from our rice trial plots also showed that pesticide use in GM plots and non-GM plots differed significantly. Farmers sprayed pesticides 1.38 times $\left(3.71 \mathrm{~kg} \mathrm{hm}^{-2}\right)$ in their GM plots, and 2.72 times $\left(13.06 \mathrm{~kg} \mathrm{hm}^{-2}\right)$ and 5.60 times (46.75 $\mathrm{kg} \mathrm{hm}^{-2}$ ) in non-GM rice plots ${ }^{4)}$. During the survey, we also recorded all the inputs and output of all rice plots sampled. The data in the two villages where both GM and non-GM rice were planted showed that the average yield of plots planted with GM varieties was slightly higher than that planted with non-GM varieties. The results of crop performance comparison between GM and non-GM rice in this study were consistent with previous studies [1].

The significant and new finding is that reduction of pesticide use has important effects on farmers' health. Health examination results indicated that pesticide use within $24 \mathrm{~h}$

2) After poisoning, the accumulated acetylcholine affects the postganglionic cholinergic nerve to excite the parasympathetic nerve ending, which yields the clinical manifestations of increased activities of smooth muscle and glands, such as sweating, salivation, and vomiting [13]. As a result, the effective circulating bloods volume decreases and both the values of RBC and $\mathrm{N}$ increase. Clinical observations also showed that the values of RBC and $\mathrm{N}$ increased significantly after pesticide poisoning [14].

3) Chloride ions $\left(\mathrm{Cl}^{-}\right)$along with sodium ions $\left(\mathrm{Na}^{+}\right)$play important roles in plasma crystal colloid osmotic pressure. The main components of plasma electrolytes are positive and negative ions, while chloride is the major negative ion and sodium is the major positive ion in plasma electrolytes [15]. The mechanism that pesticide affects chloride and sodium ions in blood is still not clear. In empirical studies, some observed an increased concentration of sodium after pesticide exposure [16,17], while the others reported loss of chloride and sodium ions [16,18].

4) The farmers in the villages without GM rice trail used much more pesticides than those in the village without GM rice trial. While the exact reasons for this difference are not clear and need further study, there are two possible explanations. First is the difference in local landscape and therefore the severity of pest problem. Paddy field in the village with GM rice trial is surrounded by mountain, tree, water and grassland, while the landscape in the village without GM rice trial is full of large paddy field. Studies have shown that diverse landscapes in general support greater natural enemy abundance and enhanced pest control or reduce pesticide use in agricultural landscapes [21-23]. Second, it may also suggest that GM rice protects the adjacent non-GM rice from the insect damage in the GM rice trial village. 
Table 1 Characteristics of households, pesticide use, acute poisoning cases, and rice production in two villages with GM rice trials, and one village without a GM rice trial

\begin{tabular}{|c|c|c|c|}
\hline & \multicolumn{2}{|c|}{ Two villages with GM rice trials } & \multirow{2}{*}{$\begin{array}{c}\text { One village without GM rice } \\
\text { trial }\end{array}$} \\
\hline & GM rice adopter & Non-GM rice adopter & \\
\hline No. of household & 20 & 38 & 51 \\
\hline Cultivated land $\left(\mathrm{hm}^{2}\right)$ & 0.18 & 0.15 & 0.36 \\
\hline Acute poisoning cases $(\%)$ & $0.00^{\mathrm{a})}$ & 0.08 & 0.08 \\
\hline \multicolumn{4}{|l|}{ In rice trial plots ${ }^{\text {b) }}$} \\
\hline Frequency of pesticide use (times) & 1.38 & 2.72 & 5.60 \\
\hline Amount of pesticide use $\left(\mathrm{kg} \mathrm{hm}^{-2}\right)$ & 3.71 & 13.06 & 46.75 \\
\hline Cost of pesticide use $\left(\mathrm{RMB} \mathrm{hm} \mathrm{hm}^{-2}\right)$ & 187.07 & 507.78 & 1044.70 \\
\hline Rice yield plots $\left(\mathrm{t} \mathrm{hm}^{-2}\right)$ & 8.21 & 8.04 & 10.84 \\
\hline
\end{tabular}

a) No farmers reported any acute poisoning symptoms during working in the GM rice fields. b) The data in rice trial plots correspond to GM rice plots in the two villages with GM rice trials, non-GM plots in the two villages with GM rice trials, and non-GM plots in the third village.

had a significant impact on the magnitude of various health indicators (Table 2). For example, the average $N$ value decreased from 60.95 at the first test to 56.22 at the second test in farmers who sprayed pesticides within $24 \mathrm{~h}$ before the second blood test (row 4). However, the average change in $N$ between the two blood tests was not significant if pesticide exposure occurred more than $24 \mathrm{~h}$ prior to the second test (Table 2). A similar pattern was observed in all other health indicators (rows 1-3 and rows 5-8) though the differences were not significant for the indicators related to the nervous system (rows 1-3).

The estimated coefficients on pesticide use, when measured either by dummy variables or the actual amount of pesticide sprayed (Table 3 ), were negative and statistically significant, which means that $\mathrm{CHE}$ values decreased following pesticide exposure. For example, the average value of $\mathrm{CHE}$ decreased by 32.03 within $24 \mathrm{~h}$ of pesticide exposure (row 1). The estimation results additionally showed that the effect would not be observed more than $24 \mathrm{~h}$ after pesticide exposure. Similarly, as shown in the third column, if farmers sprayed pesticides within $24 \mathrm{~h}$ before the blood test, the value of NSE, another indicator of nervous system, may increase by 1.94 (or $34.28 \%$ ).

The regression analysis showed that pesticide use exerted a significant short-term influence on the measured hematological indicators. $N$ values decreased by 5.25 , and $R B C$ values decreased by 0.08 (Table 3 , columns 5 and 7) in farmers who reported pesticide exposure within $24 \mathrm{~h}$ of the blood test. Similar to the effects on $C H E$, the impact of pesticide use on $N$ and $R B C$ were mainly evident the first day after pesticide exposure. This remained true, if the quantity of pesticide was used as an explanatory variable (Table 3).

Significant effects of pesticide use within $24 \mathrm{~h}^{\circ} \mathrm{Cl}^{-}$and
$\mathrm{Na}^{+}$were also found using the econometric analysis (Table 3 , columns 9-12). The estimation results showed that pesticide use increased $\mathrm{Cl}^{-}$and $\mathrm{Na}^{+}$values in farmers. Similar to the impact on the neurological and hematological system, the effect of pesticide exposure was not significant after 24 h.

We assessed whether pesticide use leads to changes in the health indicators by re-estimating our models and assigning the abnormal readings of these indicators as dependent variables. An increase or decrease in the above health indicators may have still been within the normal range. In this study, we define the system abnormal if at least one of the two related indicators is abnormal (i.e., greater than the upper bound or less than the lower bound of the normal range). Estimation results are shown in Table 4. The regression results showed that pesticide use affected not only the magnitude of these indicators (Table 3), but also the normal function of nervous and hematological systems, as shown in Table $4^{5)}$. Similar to the impact on the magnitudes of these indicators, the impact on abnormal readings of nervous system and hematological system was also detected only when pesticides were sprayed within $24 \mathrm{~h}$.

\section{Discussion}

This study shows that commercialization of GM rice may reduce pesticide use by more than $2 / 3$. This equals a national pesticide reduction of more than $196,000 \mathrm{t}$, or about 6 billion RMB, annually ${ }^{6}$. More importantly, this study provides new evidence on the benefits of GM technology to the health of farmers.

It should be noted that $8 \%$ of rice farmers still suffer

5) Since all the values of body fluid at the first blood test were in normal range, and only one was abnormal at the second blood test, we did not run regression for abnormal reading of body fluid. In addition, we ran fixed effect OLS models since most observations would be dropped due to all positive or all negative outcomes if fixed effect Logit models were estimated.

6) China's rice area is about 30 million $\mathrm{hm}^{2}$ in 2011 [19]. If we assume $70 \%$ of rice area planted with GM rice (the share of indica rice was about $70 \%$ in China), the saving of the pesticide use could reach 196 million $\mathrm{kg}\left((13.06-3.71) \mathrm{kg} \mathrm{hm}^{-2} \times 30\right.$ million hm $\left.\mathrm{hm}^{-2} \times 70 \%=196,350 \mathrm{t}\right)$, or more than 6 billion RMB (30 million $\mathrm{hm}^{2} \times(507.78-187.07) \mathrm{RMB} \mathrm{hm}{ }^{-2} \times 70 \%=6.73$ billion $\left.\mathrm{RMB}\right)$. 
Table 2 Values of health indicators by time (h) of pesticide use between farmers' last exposure and the second blood test ${ }^{\mathrm{a}}$

\begin{tabular}{|c|c|c|c|c|c|c|c|c|c|}
\hline & \multicolumn{3}{|c|}{ Less than $24 \mathrm{~h}$} & \multicolumn{3}{|c|}{$24-48 \mathrm{~h}$} & \multicolumn{3}{|c|}{$48-72 \mathrm{~h}$} \\
\hline & 1 st test & 2nd test & $t$-test & 1 st test & 2nd test & $t$-test & $1 \mathrm{st}$ test & 2nd test & $t$-test \\
\hline \multicolumn{10}{|l|}{ Nervous system } \\
\hline Cholinesterase (CHE) & 232.57 & 199.71 & 1.39 & 234.36 & 240.43 & 0.34 & 256.88 & 259.13 & 0.05 \\
\hline Neuron-specific enolase(NSE) & 4.93 & 6.67 & 1.48 & 5.44 & 5.23 & 0.15 & 6.32 & 5.77 & 0.34 \\
\hline Abnormal reading ${ }^{*}$ & 0.38 & 0.62 & 1.55 & 0.21 & 0.14 & 0.48 & 0.25 & 0.25 & 0.00 \\
\hline \multicolumn{10}{|l|}{ Hematological system } \\
\hline Neutrophil granulocyte \% (N) & 60.95 & 56.22 & 2.82 & 55.10 & 57.41 & 0.77 & 59.38 & 59.29 & 0.03 \\
\hline Red blood cell count (RBC) & 4.61 & 4.54 & 0.57 & 4.60 & 4.67 & 0.64 & 4.86 & 4.87 & 0.03 \\
\hline Abnormal reading ${ }^{*}$ & 0.05 & 0.33 & 2.47 & 0.57 & 0.36 & 1.12 & 0.13 & 0.25 & 0.61 \\
\hline \multicolumn{10}{|l|}{ Blood electrolytes } \\
\hline Chloride $\left(\mathrm{Cl}^{-}\right)$ & 99.73 & 101.25 & 2.27 & 100.74 & 100.56 & 0.32 & 100.24 & 100.50 & 0.39 \\
\hline Sodium $\left(\mathrm{Na}^{+}\right)$ & 138.78 & 140.07 & 2.19 & 140.31 & 139.94 & 0.61 & 140.40 & 140.20 & 0.26 \\
\hline Abnormal reading ${ }^{*}$ & 0.00 & 0.00 & & 0.00 & 0.00 & & 0.00 & 0.00 & \\
\hline
\end{tabular}

a) Values are means and $t$-statistics. Source: Authors' survey. *, Normal range of each of measured health indicators are as follows: $203.0-460.0$ (U L ${ }^{-1}$ ) for CHE, 0.0-15.0 $\left(\mathrm{Ng} \mathrm{mL}^{-1}\right)$ for NSE, 4.0-10.0 $\left(109 \mathrm{~L}^{-1}\right)$ for $\mathrm{WBC}, 55.0-75.0\left(109 \mathrm{~L}^{-1}\right)$ for $\mathrm{N}, 96.0-106.0\left(\mathrm{mmol} \mathrm{L}^{-1}\right)$ for $\mathrm{Cl}^{-}, 135.0-145.0\left(\mathrm{mmol} \mathrm{L}^{-1}\right)$ for $\mathrm{Na}^{+}$.

Table 3 Estimated parameters using an individual fixed-effects model for estimating the effect of pesticide use on farmers' health indicators in China ${ }^{\text {a) }}$

\begin{tabular}{|c|c|c|c|c|c|c|c|c|c|c|c|c|}
\hline & \multicolumn{2}{|c|}{ Cholinesterase (CHE) } & \multicolumn{2}{|c|}{$\begin{array}{c}\text { Neuron-specific } \\
\text { enolase }(N S E)\end{array}$} & \multicolumn{2}{|c|}{$\begin{array}{c}\text { Neutrophil } \\
\text { granulocyte \% }(N)\end{array}$} & \multicolumn{2}{|c|}{ Red blood cell $(R B C)$} & \multicolumn{2}{|c|}{ Chloride $\left(\mathrm{Cl}^{-}\right)$} & \multicolumn{2}{|c|}{ Sodium $\left(\mathrm{Na}^{+}\right)$} \\
\hline & $\begin{array}{c}\text { Pesticide } \\
\text { dummy } \\
\text { (yes=1) }\end{array}$ & $\begin{array}{c}\text { Pesticide } \\
\text { quantity } \\
(\mathrm{kg})\end{array}$ & $\begin{array}{c}\begin{array}{c}\text { Pesticide } \\
\text { dummy } \\
\text { (yes }=1)\end{array} \\
\end{array}$ & $\begin{array}{c}\text { Pesticide } \\
\text { quantity } \\
(\mathrm{kg})\end{array}$ & $\begin{array}{c}\text { Pesticide } \\
\text { dummy } \\
(\text { yes }=1)\end{array}$ & $\begin{array}{c}\text { Pesticide } \\
\text { quantity } \\
(\mathrm{kg})\end{array}$ & $\begin{array}{c}\text { Pesticide } \\
\text { dummy } \\
\text { (yes }=1)\end{array}$ & $\begin{array}{c}\text { Pesticide } \\
\text { quantity } \\
(\mathrm{kg})\end{array}$ & $\begin{array}{c}\text { Pesticide } \\
\text { dummy } \\
\text { (yes }=1 \text { ) }\end{array}$ & $\begin{array}{c}\text { Pesticide } \\
\text { quantity } \\
(\mathrm{kg})\end{array}$ & $\begin{array}{c}\text { Pesticide } \\
\text { dummy } \\
\text { (yes=1) }\end{array}$ & $\begin{array}{c}\text { Pesticide } \\
\text { quantity } \\
(\mathrm{kg})\end{array}$ \\
\hline \multicolumn{13}{|c|}{ Number of hours between exposure and blood test } \\
\hline$<24 \mathrm{~h}$ & $\begin{array}{l}-32.03 \\
(-6.09)^{* *}\end{array}$ & $\begin{array}{l}-43.98 \\
(-5.17)^{* *}\end{array}$ & $\begin{array}{l}1.94 \\
(1.90)\end{array}$ & $\begin{array}{c}3.37 \\
(2.14)^{*}\end{array}$ & $\begin{array}{c}-5.25 \\
(-2.75)^{* * *}\end{array}$ & $\begin{array}{c}-7.23 \\
(-2.40)^{*}\end{array}$ & $\begin{array}{c}-0.08 \\
(-1.99)^{*}\end{array}$ & $\begin{array}{l}-0.10 \\
(-1.63)\end{array}$ & $\begin{array}{c}1.57 \\
(3.10)^{* * *}\end{array}$ & $\begin{array}{c}1.94 \\
(2.40)^{*}\end{array}$ & $\begin{array}{c}1.28 \\
(3.02)^{* * *}\end{array}$ & $\begin{array}{c}1.89 \\
(2.86)^{* *}\end{array}$ \\
\hline $24-48 \mathrm{~h}$ & $\begin{array}{c}5.56 \\
(0.96)\end{array}$ & $\begin{array}{l}16.01 \\
(1.20)\end{array}$ & $\begin{array}{l}-0.19 \\
(-0.17)\end{array}$ & $\begin{array}{l}-0.60 \\
(-0.24)\end{array}$ & $\begin{array}{c}3.00 \\
(1.42)\end{array}$ & $\begin{array}{c}2.80 \\
(0.59)\end{array}$ & $\begin{array}{c}0.07 \\
(1.67)\end{array}$ & $\begin{array}{c}0.19 \\
(2.00)^{*}\end{array}$ & $\begin{array}{c}0.07 \\
(0.12)\end{array}$ & $\begin{array}{c}0.06 \\
(0.05)\end{array}$ & $\begin{array}{l}-0.11 \\
(-0.24)\end{array}$ & $\begin{array}{l}-1.11 \\
(-1.08)\end{array}$ \\
\hline $48-72 \mathrm{~h}$ & $\begin{array}{c}2.85 \\
(0.42)\end{array}$ & $\begin{array}{l}14.17 \\
(0.97)\end{array}$ & $\begin{array}{l}-0.13 \\
(-0.10)\end{array}$ & $\begin{array}{l}1.56 \\
(0.58)\end{array}$ & $\begin{array}{c}0.42 \\
(0.17)\end{array}$ & $\begin{array}{l}-1.15 \\
(-0.22)\end{array}$ & $\begin{array}{c}0.04 \\
(0.77)\end{array}$ & $\begin{array}{c}0.12 \\
(1.19)\end{array}$ & $\begin{array}{l}0.61 \\
(0.92)\end{array}$ & $\begin{array}{c}0.42 \\
(0.30)\end{array}$ & $\begin{array}{l}-0.09 \\
(-0.17)\end{array}$ & $\begin{array}{l}-0.42 \\
(-0.37)\end{array}$ \\
\hline Constant & $\begin{array}{c}225.12 \\
(157.41)^{* *}\end{array}$ & $\begin{array}{c}224.12 \\
(151.66)^{* * *}\end{array}$ & $\begin{array}{c}5.66 \\
(20.41)^{* * *}\end{array}$ & $\begin{array}{c}5.63 \\
(20.54)^{* * *}\end{array}$ & $\begin{array}{c}58.01 \\
(111.79)^{* * *}\end{array}$ & $\begin{array}{c}58.09 \\
(111.09)^{* * *}\end{array}$ & $\begin{array}{c}4.62 \\
(443.17)^{* * *}\end{array}$ & $\begin{array}{c}4.61 \\
(443.04)^{* * *}\end{array}$ & $\begin{array}{c}100.63 \\
(731.15)^{* * *}\end{array}$ & $\begin{array}{c}100.71 \\
(719.56)^{* * *}\end{array}$ & $\begin{array}{c}139.95 \\
(1217.15)^{* * *}\end{array}$ & $\begin{array}{c}140.01 \\
(1222.38)^{* * *}\end{array}$ \\
\hline$R^{2}$ & 0.26 & 0.21 & 0.03 & 0.05 & 0.08 & 0.06 & 0.06 & 0.06 & 0.09 & 0.05 & 0.08 & 0.08 \\
\hline
\end{tabular}

a) Values are means and $t$-statistics (in parentheses). The symbols * and ** denote significance at $5 \%$ and $1 \%$, respectively. The number of observations used in regression was 218. Data are from the authors' survey.

Table 4 The impact of pesticide use on indicators of the neurological system, hematological system, and blood electrolytes ${ }^{\mathrm{a})}$

\begin{tabular}{|c|c|c|c|c|}
\hline & \multicolumn{2}{|c|}{ Abnormal reading of the neurological system } & \multicolumn{2}{|c|}{ Abnormal reading of the blood system } \\
\hline & Pesticide dummy (yes $=1$ ) & Pesticide Quantity (kg) & Pesticide dummy (yes=1) & Pesticide Quantity (kg) \\
\hline \multicolumn{5}{|c|}{ Number of hours between exposure and blood test } \\
\hline \multirow[t]{2}{*}{ Less than $24 \mathrm{~h}$} & 0.23 & 0.44 & 0.33 & 0.39 \\
\hline & $(3.50)^{* *}$ & $(4.47)^{* *}$ & $(2.58)^{*}$ & $(1.92)$ \\
\hline \multirow[t]{2}{*}{$24-48 \mathrm{~h}$} & -0.01 & -0.14 & -0.18 & 0.08 \\
\hline & $(-0.18)$ & $(-0.92)$ & $(-1.32)$ & $(0.27)$ \\
\hline \multirow[t]{2}{*}{$48-72 \mathrm{~h}$} & 0.00 & -0.11 & 0.00 & 0.01 \\
\hline & $(0.00)$ & $(-0.62)$ & $(0.00)$ & $(0.02)$ \\
\hline \multirow[t]{2}{*}{ Constant } & 0.41 & 0.42 & 0.30 & 0.30 \\
\hline & $(23.38)^{* *}$ & $(24.52)^{* *}$ & $(8.83)^{* *}$ & $(8.50)^{* *}$ \\
\hline$R^{2}$ & 0.10 & 0.16 & 0.07 & 0.04 \\
\hline
\end{tabular}

a) Values are means and $t$-statistics (in parentheses). The symbols * and ** denote significance at $5 \%$ and $1 \%$, respectively. The number of observations used in regression was 218. Data are from the authors' survey. 
from acute pesticide-related poisoning. According to the national statistics, the average pesticide level per $\mathrm{hm}^{2}$ for cash crops is even higher than that of rice [24], and there are more than 200 million farming households in China. Thus, the estimated 16 million farmers who suffer acute poisoning illnesses each year can benefit from the use of GM technology and the consequent reduction in pesticide exposure.

More importantly, this study provides empirical new evidences on the benefits of GM technology to farmers' health. Our results show that GM technologies such as GM rice can significantly improve farmers' health through avoiding incidence of pesticide-related illness (or visible effect) and invisible short time effects on farmers' neurological system, hematological system and blood electrolytes.

While most of the effects observed in this study are short-term (e.g., invisible effects within $24 \mathrm{~h}$ ), farmers spray pesticides many times during the entire crop-growing season. It follows that frequent short-term effects may affect the long-term health of farmers. Thus, further examination of this is necessary.

This work was supported by the International Development Research Center (106160-002), the National Natural Science Foundation of China (71333013, 71210004) and National Key Program on Genetically Modified New Varieties (2011ZX08015-002A).

1 Huang J, Hu R, Rozelle S, Pray C. Insect-resistant GM rice in farmers' fields: assessing productivity and health effects in China. Science, 2005, 308: 688-690

2 Pray C, Ma D, Huang J, Qiao F. Impact of Bt cotton in China. World Dev, 2001, 29: 813-825

3 James C. Global Status of Commercialized Biotech/GM Crops: 2012, ISAAA Brief No. 44, Ithaca, NY, 2001

4 Huang J, Qiao F, Zhang L, Rozelle S. Farm pesticide, rice production, and the environment. Economy and Environment Program for Southeast Asia (EEPSEA) Res, Rep. 2001-RR3, International Development Research Center, Singapore, 2001

5 Hossain F, Pray C, Lu Y, Huang J, Fan C, Hu R. Genetically modified cotton and farmers' health in China. Int J Occup Environ Health, 2004, 10: 296-303

6 Pingali P, Hossain M, Gerpacio R. Asian Rice Bowls-The Returning Crisis? Wallingford: CABI Publishing, 1997

7 Bjørling-Poulsen M, Andersen H, Grandjean P. Potential develop- mental neurotoxicity of pesticides used in Europe. Environ Health, 2008, 7: 50-71

8 Pingali P, Marquez C, Palis F. Pesticides and Philippine rice farmer health: a medical and economic analysis. Am J Agricult Econ, 1994, 76: $587-592$

9 Deng C, Song G, Xu J, Zhu Z. Increasing accumulation level of foreign protein in transgenic plant through protein targeting. Acta Bot Sin, 2003, 45: 1084-1089

10 Eddleston M, Buckley N, Eyer P, Dawson A. Management of acute organophosphorus pesticide poisoning. Lancet, 2008, 371: 597-607

11 Qiao F, Huang J, Zhang L, Rozelle S. Pesticide use and farmers' health in China's rice production. China Agricult Econ Rev, 2012, 4: 468-484

12 Chen X, Xu L, Du J, Lv C, Zhang Z, Zhou Y, Qi K. The clinical meaning of testing serum NSE of acute organophosphorus pesticides poisoning children. Military Med J Southeast China, 2011, 13: 310

13 Wang X, Zhang G. Clinical change of red blood cell and its implications of the acutely organophosphates poisoned patients. Chin J Misdiag, 2007, 7: 966

14 Liu H, Wang J, Yang Y, Hou J. Clinical change of neuter granulocyte percentage in blood and its implications of the acutely organophosphates poisoned patients. Chin J Crit Care Med, 2003, 23: 364-365

15 Bai B, Gao M, Su L, Zhou X. Physiology, version 6. Beijing: People's Medical Publishing House, 2009

16 Logaswamy S, Radha G, Subhashini S, Logankumar K. Alterations in the levels of ions in blood and liver of freshwater fish, Cyprinus carpio var. communis exposed to dimethoate. Environ Monitor Assess, 2007, 131: 439-444

17 Eisler R, Edmunds P. Effect of endrin on blood and tissue chemistry of a marine fish. Trans Am Fish Soc, 1966, 95: 153-159

18 Grant B, Mehrle P. Chronic endrin poisoning in gold fish, Carassius auratus. J Fish Res Board Canada, 1970, 27: 2225-2232

19 National Bureau of Statistics of China. China Statistical Yearbook. Beijing: China Statistics Press, 2012a

20 National Bureau of Statistics of China. Fujian Statistical Yearbook. Beijing: China Statistics Press, 2012b

21 Landis A, Wratten D, Gurr M. Habitat management to conserve natural enemies of arthropod pests in agriculture. Ann Rev Entomol, 2000, 45: 175-201

22 Gardiner M, Landis A, Gratton C, DiFonzo D, O’Neal M, Chacon M, Wayo T, Schmidt P, Mueller E, Heimpel E. Landscape diversity enhances biological control of an introduced crop pest in the north-central USA. Ecol Appl, 2009, 19: 143-154

23 Zhou K, Huang J, Deng X, van der Werf W, Zhang W, Lu Y, Wu K, $\mathrm{Wu}$ F. Effects of land use and insecticides on natural enemies of aphids in cotton: first evidence from smallholder agriculture in the North China Plain. Agricult Ecosyst Environ, 2014, 183: 176-184

24 National Development and Reform Commission. The National Data on the Cost and Revenue of Agricultural Commodities. Beijing: China Statistics Press, 2012

Open Access This article is distributed under the terms of the Creative Commons Attribution License which permits any use, distribution, and reproduction in any medium, provided the original author(s) and source are credited. 